\title{
Analisis Kreativitas Siswa dengan Pemanfaatan Limbah Plastik dan Kertas sebagai Media Alat Peraga Biologi
}

\author{
Syafruddin \\ Universitas Samawa \\ syafruddinfkip@gmail.com
}

Abstrak: Kreativitas belajar berperan penting dalam menciptakan peseta didik yang mampu berinovasi agar dapat memenuhi kebutuhan pribadi, masyarakat dan Negara. Obsevasi awal menunjukkan bahwa guru jarang menilai kreatifitas belajar siswa, hal ini karena guru jarang memberikan tugas yang menuntut kreatifitas, padahal kreatifitas memberikan kesempatan kepada peserta didik dalam menyelesaikan permasalahan yang dihadapi dalam proses pembelajaran serta dapat mengembangkan ide baru. Penelitian ini bertujuan untuk mengetahui kreatifitas belajar siswa dengan memanfaatkan limbah plastik dan kertas sebagai media alat peraga biologi. Jenis Penelitian ini adalah penelitian Mixsed Methods Research Design. Populasi dalam penelitian ini yaitu seluruh siswa kelas VIII SMPN 5 Moyo Hilir sedangkan sampel penelitian berjumlah 49 siswa, yaitu kelas VIII-2 sebanyak 25 siswa sebagai kelas VIII-1 sebanyak 24 siswa. Teknik pengumpulan data dilakukan dengan metode observasi. Analisis data yang digunakan selama penelitian adalah analisis deskriptif dan teknik persentase. Hasil penelitian ini menunjukkan bahwa Kreatifitas siswa berdasarkan hasil observasi diperoleh kreatifitas siswa untuk kelas VIII 1 sebesar 75\% dengan kategori kreatif dan kelas VIII 2 sebesar 80\% dengan kategori kreatif. Keseluruhan hasil kreatifitas siswa kelas VIII di SMP negeri 5 Moyo hilir dengan kategori 77,5\% dengan kategori kreatif

Kata Kunci: Kreatifitas Siswa, Limbah Kertas dan Plastik, Alat Peraga Biologi.

\section{Pendahuluan}

Kreativitas merupakan bagian yang sangat penting dalam dunia pendidikan serta kehidupan sekarang. Dengan kreatifitas akan menumbuhkan inovasi dan perkembangan baru. Setiap manusia yang kreatif selalu diperlukan dalam masyarakat maupun dilingkungan mereka karena dengan ide-ide baru yang diciptakan mampu memenuhi kebutuhan di lingkungan mayarakat maupun lingkungan sekolah, sehingga mampu bertahan dalam persaingan global yang terus mengalami perkembangan yang sangat pesat. Sebuah kretifitas mampu menyelesaikan permasalahan yang dihadapi individu yang nantinya dapat memberikan kepuasan tersendiri bagi seseorang yang memiliki kreatifitas.

Kreatifitas belajar sangat dibutuhkan dalam dunia pendidikan saat ini. Guru dituntut untuk mampu menumbuhkan kreatifitas peserta didik, sehingga peserta didik nantinya siswa mampu memahami, menguasai, dan memecahkan masalah serta mampu bersaing dalam menghadapi tantangan global (Firdausi and Asikin 2018). Dalam lingkungan sekolah, sampah plastik dan kertas menjadi barang yang harus dijauhkan dari lingkungan sekolah. Padahal sampah tersebut dapat dimanfaatkan menjadi barang yang berguna. Salah satunya dapat dijadikan sebagai media pembelajaran.

Berdasarkan observasi dan wawancara dengan guru kelas VIII SMP Negeri 5 Moyo Hilir, menunjukkan bahwa guru jarang menilai kreatifitas siswa hal ini karena guru jarang memberikan tugas yang menuntut kreatifitas, padahal kreatifitas diharapkan dapat menyelesaikan masalah yang dihadapi peserta didik serta dapat menciptakan inovasi baru yang bermanfaat bagi peserta didik. Pembelajaran dilaksanakan dengan metode ceramah, diskusi dan sesekali mengadakan praktikum. Kemudian dari pembahasan diatas karakteristik dari berpikir kreatif yang diuraikan termasuk konsep berpikir divergen, pola pikir divergen erat kaitanya dengan kreativitas dalam membuat sebuah produk. Jadi, ada empat indikator dalam mengukur kreatifitas siswa yaitu kelanacaran, fleksibelitas, orisinalitas dan keluwesan. 
Guru merupakan faktor eksternal dalam memotivasi belajar siswa. Untuk itu diperlukan kreativitas dari guru dalam meningkatkan motivasi belajar siswa. Peningkatan kreativitas siswa bisa melalui penerapan metode pembelajaran yang tepat, pemilihan media pembelajaran yang inovatif. Sehingga pembelajaran yang dulunya berpusat kepada guru, kini pembelajaran yang terpusat pada siswa. Guru yang memiliki kreativitas adalah motivator sekaligus contoh bagi siswanya (Oktiani 2017).

Media pembelajaran menggunakan alat peraga merupakan metode pembelajaran yang menjadikan siswa untuk mampu berfikir secara ilmiah sehingga nantinya mampu memecahkan masalah sehingga peserta didik lebih aktif dalam proses pembelajaran dalam mengembangkan kreatifitas. Selama beberapa dekade terakhir, pendidik dalam hal ini guru telah fokus pada kebutuhan khusus perserta didik Oleh karena itu, kemampuan kreativitas dan pemecahan masalah peserta didik diidentifikasikan sebagai faktor utama dalam mencapai tujuan pendidikan. Berfikir kreatif dapat diartikan sebagai seluruh rangkaian aktifitas kognitif yang digunakan oleh individu menurut objek tertentu berdasarkan masalah dan kondisi, atau jenis berdasarkan masalah peserta didik (Young and Balli 2014).

\section{Metode Penelitian}

Penelitian ini adalah penelitian Mixsed Methods Research Design. Adapun populasi dalam penelitian ini adalah seluruh siswa kelas VIII di SMP Negeri 5 Sumbawa. Sampel dalam penelitian ini adalah siswa kelas VIII SMP Negeri 5 Sumbawa berjumlah 49 orang yang terdiri dari 2 kelas yaitu kelas VIII A berjumlah 25 siswa dan kelas VIIIB berjumlah 25 kelas. Instrument dalam penelitian ini adalah lembar observasi kreatifitas siswa. Teknik pengumpulan data dilakukan dengan metode observasi dengan indikator kelancaran, fleksibilitas, dan orisinalitas dan wawancara. Analisis data yang digunakan selama penelitian adalah analisis deskriptif kualitatif dan teknik persentase untuk mengolah data hasil observasi siswa (data kuantitatif) dihitung dengan rumus berikut ini:

Keterangan :

$$
P=\frac{M}{S M I} \times 100 \%
$$

$\mathrm{M} \quad$ = Rata-rata skor observasi siswa

$\mathrm{P} \quad=$ Porsentase skor observasi siswa

SMI = Skor maksimal ideal berikut:

Penentuan tingkat kreatifitas belajar biologi siswa sesuai dengan skala konversi yang terdapat pada tabel

Tabel 1. Konversi Persentase Kreatifitas Belajar Siswa

\begin{tabular}{ccc}
\hline No & Persentase & Kategori \\
\hline 1 & $0 \%-20 \%$ & Tidak kreatif \\
2 & $21 \%-40 \%$ & Kurang kreatif \\
3 & $41 \%-60 \%$ & Cukup Kreatif \\
4 & $61 \%-80 \%$ & Kreatif \\
5 & $81 \%-100$ & Sangat kreatif \\
\hline \multicolumn{2}{r}{ (Arini 2017) }
\end{tabular}

\section{Hasil dan Pembahasan}

Variabel dalam penelitian ini yaitu pembelajaran IPA Biologi yang memanfaaatkan limbah plastik dan kertas sebagai alat peraga sebagai variabel bebas dan kreatifitas belajar biologi siswa sebagai variable terikat. Dalam proses pembelajaran dikelas siswa diminta untuk membawa limbah dari rumah berupa botol plastik dan kertas bekas yang nantinya akan dibuat alat peraga. Alat peraga yang dihasilkan oleh siswa kemudian dinilai sebagai kreatifitas belajar biologi siswa. Berdasarkan lembar observasi penilaian yang dibuat peneliti mengenai pengamatan langsung saat proses pembelajaran didalam kelas, maka hasil observasi dikonversi dalam kategori yang dapat dilihat pada tabel berikut:

Tabel 2. Hasil Kreatifitas Belajar Biologi Siswa 


\begin{tabular}{ccc}
\hline Kelas & Persetase & Kategori \\
\hline VIII 1 & $75 \%$ & Kreatif \\
VIII 2 & $80 \%$ & Kreatif \\
\hline Rata-rata & $77,5 \%$ & Kreatif \\
\hline
\end{tabular}

(Sumber: Data Pribadi yang Diolah, 2020)

Berdasarkan hasil persentase diatas dapat disimpulkan bahwa kreatifitas siswa untuk kelas VIII 1 sebesar 75\% dengan kategori kreatif dan kelas VIII 2 sebesar 80\% dengan kategori kreatif. Rata-rata untuk kreatifitas belajar biologi siswa sebesar 77,5\% dengan kategori kreatif. Hasil penelitian ini diperkuat oleh (Sum et al. 2020) yang menyatakan bahwa media pembelajaran IPA berbasis masalah sangat efektif dalam meningkatkan kreativitas mahasiswa calon guru SD. Berpikir kreatif siswa dengan efikasi diri tinggi dan siswa dengan efikasi rendah rendah berbeda pada tahap persiapan sehinnga sangat tepat dalam menyelesaikan masalah dalam pembelajaran (Husnul Khatimah and Fatmah 2019). Memberikan sebuah reword bagi prestasi kreatif serta memberikan keleluasaan kepada siswa melalui peningkatan berfikir kreatif dengan berbagai macam media (Kenedi 2017) .

Kreativitas merupakan aspek penting dari perkembangan manusia. Tren menuju globalisasi dengan perkembangan teknologi membutuhkan manusia yang produktif dan inovatif di semua lapisan masyarakat. Kreativitas sangat dibutuhkan di perkembangan awal pikiran seseorang. Institusi pendidikan adalah tempat terpenting untuk menumbuhkan bakat-bakat kreatif dan kemampuan peserta didik serta sebagai media penting dalam pembangkitan budaya kreatif peserta didik. sains Pembelajaran Sains di lembaga pendidikan dipandang sebagai mata pelajaran yang dapat membantu meningkatkan kualitas berpikir kreatif di kalangan peserta didik. Diantara tantangan yang dihadapi dalam penanaman keterampilan berpikir kreatif dalam pembelajaran dan pengajaran adalah pengetahuan guru tentang pengajaran kreativitas, bukan untuk menekankan penerapan kreativitas oleh guru, siswa yang pemalu dan tidak mau untuk menunjukkan kreativitas mereka (Daud et al. 2012). Penilaian kreativitas peserta didik di seluruh mata pelajaran dapat dikembangkan melalui pertimbangan kerangka kerja yang ada untuk menilai dan mendukung kreativitas (Blamires and Peterson 2014).

Berdasarkan indikator aspek kretaivitas, peserta didik peserta didik dilatih untuk berfikir (fluency of thinking), dengan berfikir peserta didik mampu untuk mengembangkan banyak ide dalam memecahkan berbagai macam soal yang menuntuk untuk berfikir kritis misalnya mennghasilkan ide baru, membuat pertanyaan dan jawaban yang lebih variatif dan menuntuk untuk berfikir tingkat tinggi, melihat permasalahan yang dihadapi dari sudut pandang yang berbeda, mampu menggunakan bermacam-macam pendekatan atau cara pemikiran (Muhamad Ajwar et al. 2019). Penelitian yang dilaksanakan oleh Hairunisa (2019) menyatakan bahwa menerapkan model pembelajaran yang inovatif dapat meningkatkan kreativitas mahasiswa secara signifikan. Kreativitas mahasiswa dalam mengolah sampah menjadi alat peraga dapat meningkatkan kemampuan berfikir mahasiswa sehingga kreatifitas juga akan muncul (Hairunisa, Arif Rahman Hakim, and Nurjumiati 2019).

Pembelajaran dengan menggunakan alat peraga merupakan kegiatan pembelajaran yang memanfaatkan suatu alat/benda untuk dijadikan objek pembelajaran. Alat peraga berfungsi untuk mempermudah guru dalam menyampaikan materi pembelajaran sehingga diharapkan dapat mencapai kompetensi pembelajaran. Media pembelajaran yang digunakan oleh guru dapat dijadikan sebagai ruang bagi siswa dalam melakukan eksperimen, siswa menjadi lebih aktif dalam belajar, mengemukakan pendapat atau memberikan ide-ide kretaif, mencoba hal- hal baru yang belum pernah dilakukan sebelumnya (Fitria Sarnita, Ainun Fitriani, and Widia 2019). Media pembelajar inovatif juga berpengaruh terhadap kreativitas sehingga berdampak pada hasil belajar siswa (Silaban and Napitupulun 2011).

Hasil penelitian ini diperkuat oleh teori yang mengungkapkan bahwa biologi sebagai cabang Ilmu Pengetahuan Alam yang berkembang melalui kegiatan ilmiah seperti melakukan observasi, perumusan masalah, penyusunan hipotesis penelitian, menyimpulkan, serta menghasilkan teori dan konsep baru (Trianto 2010). Pembelajaran IPA khususnya Biologi menggunakan alat peraga sudah seharusnya menjadi model pembelajaran yang digemari oleh siswa dalam pembelajaran, karena sangat membantu siswa terutama dalam mengembangkan keterampilan berfikir Kritis dan kreatifitas siswa (Yazar Soyadı 2015).

\section{Simpulan}


Kreatifitas belajar biologi siswa di SMP Negeri 5 Moyo Hilir berdasarkan hasil observasi diperoleh kreatifitas siswa untuk kelas VIII 1 sebesar 75\% dengan kategori kreatif dan kelas VIII 2 sebesar 80\% dengan kategori kreatif, rata-rata kreatifitas belajar siswa sebesar 77,5\% dengan kategori kreatif.

\section{Ucapan Terima Kasih}

Ucapan terima kasih tak terhingga penulis sampaikan kepada Kepala Sekolah SMP Negeri 5 Moyo Hilir yang telah mengijinkan peneliti dan diterima dengan baik pada saat penelitian, memfasilitasi kegiatan penelitian. Ucapan terima kasih pula peneliti sampaikan kepada guru mata pelajaran IPA yang bersedia memberikan pengalaman serta data pada saat observasi awal penelitian. Tidak lupa pula peneliti sampaikan terima kasih kepada siswa kelas VIII yang telah membantu peneliti pada saat penelitian sehingga penelitian ini berjalan dengan baik.

\section{Daftar Pustaka}

Arini, Wahyu. 2017. "Analisis Kemampuan Berpikir Kreatif Pada Materi Cahaya Siswa Kelas Delapan Smp Xaverius Kota Lubuklinggau.” Science and Physics Education Journal (SPEJ). doi: 10.31539/spej.v1i1.41.

Blamires, Mike, and Andrew Peterson. 2014. "Can Creativity Be Assessed? Towards an Evidence-Informed Framework for Assessing and Planning Progress in Creativity." Cambridge Journal of Education. doi: 10.1080/0305764X.2013.860081.

Daud, Adzliana Mohd, Jizah Omar, Punia Turiman, and Kamisah Osman. 2012. "Creativity in Science Education.” Procedia - Social and Behavioral Sciences. doi: 10.1016/j.sbspro.2012.09.302.

Firdausi, Y. N., and M. Asikin. 2018. "Analisis Kemampuan Berpikir Kreatif Siswa Ditinjau Dari Gaya Belajar Pada Pembelajaran Model Eliciting Activities ( MEA ).” in FMIPA, Universitas Negeri Semarang, Semarang usiyusrotin@gmail.com.

Fitria Sarnita, Ainun Fitriani, and Widia. 2019. "Pengembangan Perangkat Pembelajaran Model PBL Berbasis STEM Untuk Melatih Keterampilan Berfikir Kreatif Siswa Tuna Netra.” JURNAL PENDIDIKAN MIPA. doi: $10.37630 /$ jpm.v9i1.180.

Hairunisa, Arif Rahman Hakim, and Nurjumiati. 2019. "Studi Pengaruh Model Pembelajaran Berbasis Proyek (Project Based Learning) Terhadap Kreativitas Mahasiswa Program Studi PGSD Pada Mata Kuliah Konsep Dasar IPA.” JURNAL PENDIDIKAN MIPA. doi: 10.37630/jpm.v9i2.190.

Husnul Khatimah, and Fatmah. 2019. "Proses Berpikir Kreatif Dalam Menyelesaikan Masalah Matematika Ditinjau Dari Self Efficacy.” JURNAL PENDIDIKAN MIPA. doi: 10.37630/jpm.v9i2.237.

Kenedi. 2017. "Pengembangan Kreativitas Siswa Dalam Proses Pembelajaran Di Kelas II SMP Nergeri 3 Rokan IV Koto." Jurnal Ilmu Pendidikan Sosial, Sains, Dan Humaniora.

Muhamad Ajwar, Mariamah, Hardiansyah, and Syahriani Yulianci. 2019. "Penggunaan Open Ended Untuk Meningkatkan Kreativitas Belajar Mahasiswa Pada Mata Kuliah Konsep Dasar IPA.” Jurnal Pendidikan Mipa 9(1):10-14. doi: 10.37630/jpm.v9i1.154.

Oktiani, Ifni. 2017. “Kreativitas Guru Dalam Meningkatkan Motivasi Belajar Peserta Didik.” Jurnal Kependidikan. doi: 10.24090/jk.v5i2.1939.

Silaban, Ramlan, and Masita Anggraini Napitupulun. 2011. "Pengaruh Media Mind Mapping Terhadap Kreativitas Dan Hasil Belajar Kimia Siswa SMA Pada Pembelajaran Menggunakan Advance Organizer.” Jurnal.

Sum, Suriya Ningsyih, Syahriani Yulianci, Adi Apriadi Adiansha, Nurjumiati, and Asriyadin. 2020. "Efektifitas Media Pembelajaran IPA Berbasis Masalah Untuk Meningkatkan Kreativitas Mahasiswa Calon Guru SD." JURNAL PENDIDIKAN MIPA. doi: 10.37630/jpm.v10i1.285.

Trianto. 2010. "Mengembangkan Model Pembelajaran Tematik." Jakarta: PT. Prestasi.

Yazar Soyad,, Bengi Birgili. 2015. "Creative and Critical Thinking Skills in Problem-Based Learning 
Environments." Journal of Gifted Education and Creativity. doi: 10.18200/jgedc.2015214253.

Young, Mary Hahn, and Sandra Balli. 2014. "Gifted and Talented Education (GATE): Student and Parent Perspectives.” Gifted Child Today. doi: 10.1177/1076217514544030. 